\title{
Defining Aviation Management
}

\author{
Edwin D. Phillips and Robert W. Kaps \\ Southern Illinois University Carbondale
}

\begin{abstract}
The term aviation management is widely used in academia and elsewhere, yet there is no accepted definition of the term. This short article discusses separately the meaning of the constructs aviation and management and ends proposing a definition of aviation management. The intent is to initiate a dialog that results in eventual agreement on the meaning of the term among members of academia.
\end{abstract}

\section{INTRODUCTION}

In a world that has developed a vast number of experts' attention on aviation the focus seems to be on how to get large numbers of people from one destination to another safely, quickly, cheaply and profitably. The technical and financial areas garner developmental effort and dollars. But, a critical phrase in the language of travel and transportation is being ignored. The vast industry lexicon does not provide a clear understanding of the term aviation management. The author's study demonstrates a staggering number of possible meanings.

This short article reflects on the meaning of the words aviation and management and the nexus aviation management. The intent is to spur and focus dialog within the aviation academic community to reach agreement, or at least consensus, on a definition for aviation management. Informal discussions around the coffee pot, formal debate in conferences and or exchanges of views in academic journals all have potential benefit of leading to such an accord. This article explains the desirability of members of aviation management academia attempting to provide a definition.

Aviation Management has become a generic expression in academia with as many definitions as the field has practitioners. About 56 colleges or universities offer a degree in aviation management. Available research suggests that any published definition of aviation management in academic literature is illusive or non-existent (Phillips, 2004). The term has become so generic and broad that to use it risks the potential of imprecisely defining the subject being addressed. Yet, when a prospective or current student asks, "What is aviation management?" there should be some consistency of response regardless of which university or campus the question is asked.

Industry, like academia, uses the term aviation management widely with no apparent consistent meaning. Some examples are:

- The head of an aviation consulting company was asked to define the term. $\mathrm{He}$, the president, indicated he didn't have a "good explanation of the term" (S. E. Maloney, personal correspondence, April 1, 2005).

- Simpson (1991), writing from the perspective of a fixed base operator, suggests general aviation management is a post-World War II catch-all term which is hard to define precisely.

- Rodwell (1985) writes from the perspective of small business and defines aviation management as accepted theory in small business management as well as proven techniques in aviation practice.

- Richardson (1981) states that it is a generally accepted and proven managerial technique and procedure applying to the aviation setting.

- The United States Forest Service "Fire and Aviation Management" views its operation as "including operational personnel transport, research, forest rehabilitation, law enforcement support, aerial photography, infrared detection, and fire prevention and suppression" (USDA Forest Service, 2005) and goes on to state that Aviation Management is aviation technology used in fire management programs.

In summary, individuals and organizations in both academia and business use the term to 
suit their purposes without clear, consistent definition. There is no agreement or specificity as to what the term aviation management actually entails. Until our academy reaches some agreement, any definition becomes a welleducated and/or practical guess. This was recognized during the October 2004 University Aviation Association Toronto Fall Conference when the newly formed Aviation Management Committee indicated defining aviation management was a pending task (T. G. Flouris, November 28, 2004, personal correspondence).

\section{AVIATION}

This article discusses definitions of aviation and management separately and then links the two, ending with a proposed definition. First, a review of aviation:

- According to the Oxford Dictionary (2005), the oldest English lexicon in existence, the etymology of the word Aviation is rooted in the mid-nineteenth century deriving from the French language and having grown through custom and usage to assume the status of a noun that identifies the "flying or operation of an aircraft - owing its root to the Latin 'avis' (bird)" (p. 110).

- Roget's New Millennium Thesaurus (2005a) lists four nouns under the term aviation: (1) aviation, (2) air power, (3) flight, and (4) landing field. Explanation of these four terms lists forty-two separate substitute words or phrases.

- The Mariner's Museum offers a glossary for terms used to describe various historical events. Aviation is defined as "the science, business, or operation of aircraft" (mariner. org, 2005).

- The Air Force Association defines aviation as "a term applied to all phases of the manufacture and operation of aircraft" (afa.org, 2005).

- WordNet, a lexical database for the English language (Cognitive Science Laboratory Princeton University, 2005) provides three definitions:

1. aviation, air power -- (the aggregation of a country's military aircraft)
2. aviation -- (the operation of aircraft to provide transportation)

3. aviation, airmanship -- (the art of operating aircraft)

This 2005 version mysteriously omits a fourth definition used in 2003, 'travel via aircraft'. The reasons for omitting the "travel" component aviation from the 2005 version are speculative and curious.

- Wikipedia, the free online encyclopedia, broadens the definition even further stating: "Aviation or Air transport refers to the activities surrounding mechanical flight and the aircraft industry. Aircraft, include fixed wing (airplane) and rotary wing (helicopter) types, as well as lighter than air craft such as balloons and airships (also known as dirigibles.) There are two major categories of aviation: Civil aviation and Military aviation. Civil aviation includes both scheduled air transport and general aviation" (wikipedia.org,

2005).

- Wikipedia is considered a controversial source because definitions come from the worldwide public. This open forum concerning the difference between "aviation" and "air transport" resulted in a several year ongoing dialog (Talk: Aviation - Wikipedia, 2005). Participants identified 144 elements included in the term aviation.

- The National Center for Education (2005) provides a Classification of Instructional Programs. Air Transportation is positioned under Aeronautics/Aviation/Aerospace

Science and Technology, General. This is defined as "a program that focuses on the general study of aviation and the aviation industry, including in-flight and ground support operations. Includes instruction in the technical, business, and general aspects of air transportation systems" (NCES, 2005, Classification of Instructional Programs [CIP 2000]).

- The Council on Aviation Accreditation's description of the 
aviation core curriculum is illustrative of the varied views contained in the concept aviation. Core curricula for "...all students in a collegiate aviation program..." MUST include

a. Attributes of an aviation professional, career planning, and certification.

b. Aircraft design, performance, operating characteristics, and maintenance.

c. Aviation safety and human factors.

d. National and International aviation law and regulations.

e. Airports, airspace, and air traffic control.

f. Meteorology and environmental issues" (CAA, 2003, p. 12).

And, the above may be augmented by subjects that "SHOULD include a broad understanding of the components of the systems, insight into how these components function together, and an understanding of how these relate to the physical, economic, political and social environments with which these systems operate" (p. 12).

- The U.S. Department of Transportation, Bureau of Transportation Statistics (2005) provides a list of transportation expressions. Neither aviation nor aviation management are included.

The above definitions add a wide range of concepts and/or activities to the basic airplane operation offered by Oxford and include airships, helicopters and space travel. Omitted from the above are current critical aviation industry components such as frequent flyer programs, global distribution systems, air traffic control systems, etc.

Based on this background of inconsistency and equivocation the authors define aviation to be:

...the knowledge and practices associated with using an airborne vehicle for commercial, research, military or philanthropic purposes within the Earth's atmosphere.

This definition separates space travel from aviation. If aviation is on one end of a continuum and space travel another, there are instances in the middle of the continuum where the separation of the two is difficult. This overlapping middle of the continuum does not negate the validity of our view of "aviation" as a function conducted in the Earth's atmosphere and space-travel as more (pun intended) "rocket science."

\section{MANAGEMENT}

Management is a multipurpose term. A total of at least 39 synonyms exist including terms such as "administration," "command," "conduct," "control" and "top brass" (Roget's, 2005b). This suggests possible inconsistency in the use of the term. But, there is great consistency in how management - the process is defined in basic management texts. Here are seven examples presented in alphabetical order of the lead author:

1. "...Management is the process of reaching organizational goals by working with and through people and other organizational resources" (Certo, 2000 , p. 6). The management processes are planning, organizing, controlling and influencing, "also commonly referred to as motivating, leading, directing or actuating" (p. 7).

2. "The attainment of organizational goals in an effective and efficient manner through planning, organizing, leading and controlling organizational resources" (Daft \& Marcic, 2004, p. 7).

3. "...Management is defined as the process of effectively and efficiently using an organization's resources to achieve objectives through the functions of planning, organizing, leading and controlling" (DuBrin \& Ireland, 1993, p. 4)

4. "Management is a set of functions directed at the efficient and effective utilization of resources in the pursuit of organizational goals" (Griffin, 1997, p. 4). The basic management functions described by Griffin are planning and decision making, organizing, leading and controlling.

5. "The planning, organizing, leading, and controlling of resources to achieve 
organizational goals effectively and efficiently" (Jones, George, \& Hill, 2000, p. 5).

6. "...The process of getting things done, effectively and efficiently, through and with other people" (Robbins \& Decenzo, 2004, p. 6). The management processes are planning, leading, organizing and controlling.

7. "Management is getting work done through others" (Williams, 2005, p. 4). Williams expands this definition by stating managers must consider efficiency and effectiveness. He further states that the management functions are planning, controlling, organizing and leading.

Lincoln and Guba (1985) suggest that sampling can stop when redundancy is reached. When considering basic management texts used in American colleges and universities, the above definitions have reached that state - they've become redundant. Management is a process of planning, leading, organizing and controlling.

\section{AVIATION MANAGEMENT}

Based on review of a wide variety of sources and the authors' combined fifty plus years of business experience in challenging management positions with three major airlines, and after significant reflection, the recommended definition is:

"Aviation management" is the study and practice of general business processes used to achieve targeted objectives in the aviation industry.

The term "process" is used explicitly in most of the above definitions and is implicit in the others. One impact of this is to separate management - the process - from other definitions of management, such as referring to the group of people who do the managing, or using the term as an adjective or adverb, "that's just another management ploy." Our focus is on how things get accomplished - the processes used -- in the organizational world.

Another consistency in the above definitions of management is that the four basic processes are planning, leading, organizing and controlling. (Aviation students sometimes find this easy to remember with the phrase "Planes land on concrete" - P, L, O, C.) Since these four specific functions are a given component of management, repeating them in the proposed definition seems unnecessary. The summary phrase "general business processes" encompasses those terms.

This proposed definition also allows adding, as fits the perspective and context of the individuals concerned, other functions. Some might argue that safety is a separate but mandatory component of aviation and is a basic part of all aviation management processes. The proposed definition allows but does not require that viewpoint.

The authors' industry experience shows that the degree a manager is considered "effective" and "efficient" relates to whether an individual does or doesn't maintain a position and the degree to which the individual is rewarded when in the position. But, "effective" and "efficient" are meaningless without some definition such as "decrease the cost per available seat mile (CASM) by 1.2 cents by December $31^{\text {st }}$." As Daft and Marcic (2005) state, goals must be "specific and measurable" (p. 153). Organizational objectives define expected levels of effectiveness and efficiency within the context of the specific company or governmental division or department. By working toward "targeted objectives" an individual or group is attempting to be both effective and efficient as specifically defined within the context the activity takes place.

The "aviation industry" is a purposefully broad term. It can and should encompass the FAA, NTSB, military aviation, airport authorities, general and business aviation, ground service organizations that provide maintenance and fueling, industry lobby groups, global distribution system (GDS) software companies, private and corporate aviation, airport operations, Doctors Without Borders, etc. Some organizations are so broad they must be viewed on a continuum. The division of General Electric that produces jet engines is one of 11 divisions. Others are commercial finance, consumer finance and the NBC Network (GE business directory, April 6, 2005). Part of General Electric belongs in "aviation management" and part doesn't. 
Important aspects of investigating management are purposely omitted from this article. Peter Drucker is the guru who helped frame the current views of American management. His half-century of writings offer important philosophies that are best considered as part of the "study" of management. For example, he indicates that management is "the organ of the institution" that must perform three tasks: (1) establish the purpose and mission of the institution (2) make work productive and workers effective, and (3) manage social impacts and responsibilities (Drucker, 2001, p. 14). These and many other of his thoughts, and the writings of other respected management authors, provide an important richness to defining what management is and what managers (should) do. But, we believe that consideration of such aspects is an unnecessary layer for a basic working definition.

\section{CONCLUSION}

It's up to the reader to judge if, or to what degree, the logic offered above aids in answering the student's question, "What is aviation management"? From an educator's perspective the answer, based on the proposed definition, might be something like:

The field (or our program) of aviation management involves learning about how and why aviation managers accomplish important goals for their organization. This might mean putting out fires if you work for the National Forest Service, or how to reduce the number of injuries to mechanics if you are in the Air Force, or, if you work for Air West, how to increase your airline's revenues by successfully increasing fares on specific segments.

At this point, the reader has at least three options. The first is to argue that it is impossible to define the term, or any term. A definition or understanding of a term must be viewed on a continuum or semantic ladder, and where on the ladder the viewer looks results in providing meaning for the term. The viewer may consciously or unconsciously consider only the lower rungs where concepts are most tangible or may look toward the top rungs where concepts are most intangible. A "dining table" can be defined as a hard substance, made of oak, oak comes from a tree, trees consist of individual cells, cells from molecules, molecules from electrons, and electrons from "the great beyond," etc. Or, a table is a device on which to serve a meal, a meal is a cultural opportunity for sharing views by those who participate, and the thoughts generated may involve consideration of a higher power from "the great beyond." Yes, it's possible to take aviation, management or aviation management on an eclectic trip anywhere on the semantic ladder. But, for humans to jointly accomplish anything, they must come to some common understanding of terms that permits communication with one another. The authors believe that it is both possible and desirable to find a common understanding of aviation management.

A second option is to rebel at attempting to reach any type of consistent viewpoint among aviation educators and agree with Emerson that, "A foolish consistency is the hobgoblin of little minds..." (Bartlett, 2000). Some might even argue that "academic freedom" allows individual choice of what to believe and that attempts to force a consistent view on the community is unethical. An individual is certainly free to take that position. Research shows, however, that decisions made by groups are generally superior to those made by individuals and that by assisting in the process, an individual is likely to feel more valued as a professional (Andrews \& Baird, 2000).

The third option is to aid the work toward and be willing to agree upon a basic definition of aviation management for use in the academic community. Based on the authors' experience in the business world, if the field of aviation management is to move forward, the participants must have some consistent view of what they are about. The alternative is students, parents, administrators and advisory board members sensing a disjointed group of individuals who don't have any clear agreement about what it is they're doing.

You get to pick your option. 


\section{REFERENCES}

Air Force Association. (2005) www.afa.org/magazine/jan1999/0199101words.asp

Andrews, P.H. and Baird, J.E. (2000). Communication for business and the professions ( $7^{\text {th }}$. ed.). Boston: McGraw Hill.

Bureau of Transportation Statistics. (2005). Transportation expressions 1996. Retrieved April 23, 2005, Bureau of Transportation Statistics. (2004). Transportation Expressions 1996. Retrieved March 29, 2004, from http://www.bts.gov/cgi-bin/btsprod/expr/expr.pl?letter=a

Certo, S. C. (2000). Modern management: Diversity, quality ethics, \& the global environment. Upper Saddle River, NJ: Prentice Hall.

Cognitive Science Laboratory, Princeton University. (2005). Overview for aviation. Retrieved April 21, 2005, from http://www.cogsci.princeton.edu/cgi-bin/webwn2.0?stage=1\&word=aviation

Bartlett, J. (2000). Familiar quotations (10 ${ }^{\text {th }}$ ed.) Boston: Little Brown. Retrieved April 30, 2005, from http://www.bartleby.com/100/420.47.html

Daft, R. L. and Marcic, D. (2004). Understanding management ( $4^{\text {th }}$ ed.) Mason, OH: South-Western.

Drucker, P. F. (2001). The essential Drucker: The best sixty years of Peter Drucker's essential writings on management. New York: Harper.

DuBrin, A. J. and Ireland, R. D. (1993). Management \& organization ( $2^{\text {nd }}$ ed.). Cincinnati, OH: SouthWestern.

Griffin, R. W. (1997). Fundamentals of management: Core concepts and applications. Boston: Houghton Mifflin.

Jones, G. R., George, J.M. and Hill, C.W.L, (2000). Contemporary management. Boston: McGraw-Hill.

Lincoln, Y. S., and Guba, E. G. (1985). Naturalistic inquiry. Newbury Park, CA: Sage.

Mariner's Museum. (2005) Chesapeake Bay glossary. Retrieved April 11, 2005, from www.mariner.org/ chesapeakebay/century/vocab.html

NCES National Center for Education Statistics. (2005). Classification of instructional programs(CIP 2000). Retrieved April 23, 2005 from http://nces.ed.gov/pubs2002/ cip2000/ ciplist.asp? CIP2=49

The New Oxford American dictionary, $2^{\text {nd }}$ ed. (2005). Aviation. New York: Oxford University Press.

Phillips, E.D. (2004). A critique of aviation management programs. Collegiate Aviation Review, 22(1). 39 56.

Richardson, J. D. (1981). Essentials of aviation management, $2^{\text {nd }}$ Ed. New York: Kendal Hunt Publishing

Robbins, S. and Decenzo, D. (2004). Fundamentals of management: Essential concepts and applications ( $4^{\text {th }}$. ed.). Upper Saddle River, NJ: Pearson. 
Rodwell, J. F. (1985). Essentials of aviation management $3^{\text {rd }}$ Ed. New York: Kendal Hunt Publishing.

Roget's new millennium ${ }^{\mathrm{TM}}$ thesaurus, first edition. (2005a). Aviation. Retrieved April 29, 2005, from http://thesaurus.reference.com/search?q=aviation.

Roget's new millennium ${ }^{\mathrm{TM}}$ thesaurus, first edition. (2005b). Management. Retrieved April 29, 2005, from $\mathrm{http}: / /$ thesaurus.reference.com/search?q=management.

Simpson, R. W. (1991). Airlife’s general aviation. Stillwater, MN: Specialty Press Publications

USDA Forest Service. (2005). Fire and aviation management. Retrieved April 22, 2005, from http://www.fs.fed.us/fire/aviation/

Wikipedia: The free encyclopedia. (2005). Aviation. Retrieved April 11, 2005, from http://en.wikipedia.org/ wiki/Aviation

Williams, C. (2005). Management ( ${ }^{\text {rd }}$ ed.). Mason, OH: South-Western. 